\title{
Multiple giant coronary aneurysms in adult patient managed by exclusion with bypass, case report
}

\author{
S Jaber, H Altaani* \\ From 23rd World Congress of the World Society of Cardio-Thoracic Surgeons \\ Split, Croatia. 12-15 September 2013
}

\section{Background}

Aneurysm of the coronary artery is rare disease especially in adults, the most common cause is atherosclerosis, other causes are connective tissue diseases, vacuities and trauma and it could be idiopathic. The complications are ischemia, infarction or rupture. Treatment strategies include anticoagulation, custom made covered stents, reconstruction, resection, and exclusion with bypass.

\section{Case report}

A 48 year old male patient presented with angina on effort, chest $\mathrm{x}$-ray revealed increase in the cardiac shadow, CT scan showed multiple aneurismal dilatations in all coronary arteries, with evidence of calcifications, the largest one was $5 \times 5 \mathrm{~cm}$ in diameter which was in the proximal segment of left anterior descending artery extended to the proximal left main stem.

Coronary angiography showed the same results, but the distal segment of all arteries were free of dilatation, echocardiography showed normal ejection fraction.

Our management was by midsternotomy incision, partial cardiopulmonary bypass, with antegrade and retrograde cardioplegia, we bypassed the coronaries by saphenous vein graft to OM,s and PD of RCA and LIMA to distal LAD The ascending aorta was opened left main was closed from inside the aorta, the RCA was legated from its proximal segment, and just distal to the most distal aneurysm, the same done for LAD and Cx . the patient came off bypass smoothly, extubated after 4 hours and he was discharged from the hospital after 6 days with uneventfully early outcome.

* Correspondence: altaanih@gmail.com

Surgery Department, Queen Alia Heart Institute, Ammam, Jordan

\section{Conclusion}

Multiple coronary aneurysms in adults is very rare entity, ischemia is the main presenting complication, many options for treatment depend on the size, distribution, and complications, in our patient the exclusion with bypass was good option with good results but it needs long term follow-up of the patient for long term results.

Published: 11 September 2013

doi:10.1186/1749-8090-8-S1-0183

Cite this article as: Jaber and Altaani: Multiple giant coronary aneurysms in adult patient managed by exclusion with bypass, case report. Journal of Cardiothoracic Surgery 2013 8(Suppl 1):0183.

Submit your next manuscript to BioMed Central and take full advantage of:

- Convenient online submission

- Thorough peer review

- No space constraints or color figure charges

- Immediate publication on acceptance

- Inclusion in PubMed, CAS, Scopus and Google Scholar

- Research which is freely available for redistribution

Submit your manuscript at www.biomedcentral.com/submit
( Biomed Central 